\title{
An Ayurvedic Protocol to Manage Myopia in Children: A Case Series
}

\section{Sreekanth Nelliakkattu Parameswaran'1, Aravind Kumar², Krishnendu Sukumaran ${ }^{3}$}

\begin{abstract}
'M.S. (Ay), Chief Medical Officer and Secretary, Sreedhareeyam Ayurvedic Research and Development Institute, Nelliakkattu Mana, Kizhakombu, Koothattukulam, 686662, Ernakulam Dt., Kerala, India; ${ }^{2}$ M.S. (Ay), Research Coordinator, Sreedhareeyam Ayurvedic Research and Development Institute, Nelliakkattu Mana, Kizhakombu, Koothattukulam, 686662, Ernakulam Dt., Kerala, India; ${ }^{3 B A M S, ~}$ MPH, Research Coordinator, Sreedhareeyam Ayurvedic Research and Development Institute, Nelliakkattu Mana, Kizhakombu, Koothattukulam, 686662, Ernakulam Dt., Kerala, India.
\end{abstract}

\section{ABSTRACT}

Introduction: Myopia is one of the leading causes of visual impairment in children, especially schoolchildren. The most common management option is prescription of corrective spectacles, but these neither correct nor prevent progression of the error. The cardinal symptom of myopia, the inability to see distant objects, may be compared with Timira (blurring of vision) in Ayurveda.

Case Series: The cases of three children who presented to Sreedhareeyam Ayurvedic Eye Hospital with the blurring of vision and who were diagnosed with myopia are presented here.

Intervention: The children underwent specially tailored Ayurvedic treatment protocols, which included oral medicines, Netra Kriyakalpa (ocular therapeutics), and treatments for the head.

Results: Improvement in visual acuity and refraction was observed at the end of the treatments. Multiple follow-ups demonstrated either improvement or maintenance of visual acuity.

Conclusion: The main challenge for the patients was maintaining and improving vision. The results of the series indicate the potential of Ayurvedic treatments to both manage myopia and to maintain, and improve in some cases, vision in children.

Key Words: Case report, Timira, Kriyakalpa, Complementary and alternative medicine, Myopia, Children

\section{INTRODUCTION}

Uncorrected refractive errors are among the top causes of both visual impairment and blindness as per Vision 2020. ${ }^{1}$ Among these, myopia is the leading cause of visual impairment in children, with a rapid increase in prevalence. ${ }^{2}$ Myopia presents with a significant impact on both the economy and the quality of life for individuals. ${ }^{3}{ }^{4}$ Research on causal factors, possible treatments, and efforts at prevention have been spurred in light of the increasing incidence and prevalence of myopia. ${ }^{5}$ The Consortium for Refractive Error and Myopia (CREAM) study demonstrated 24 genomes with a 10 -fold increase in myopia, thus establishing that myopia's aetiology is multifactorial rather than due to a single mechanism. ${ }^{6}$ Well-organized studies demonstrate that conventional management options for myopia have either shortterm benefits or significant side effects. ${ }^{7}$ Although significant strides have been made in the field of surgical correction, they might not always be effective in the tender and delicate eyes of children. In light of the above, treatment options in contemporary and alternative medicine (CAM), including Ayurveda, may be sought.

\section{METHODOLOGY}

The cases of three children diagnosed with myopia and who underwent Ayurvedic eye treatments are presented in this series. Points regarding their history were given by their legal guardians. The CARE guidelines were adhered to for ensuring transparency and effectiveness in reporting. ${ }^{8}$ Written informed consent was obtained from the parents. Institutional ethics committee clearance was not required to prepare this series.

\section{Corresponding Author:}

Dr. Sreekanth Nelliakkattu Parameswaran, M.S. (Ay), Sreedhareeyam Ayurvedic Research and Development Institute, Nelliakkattu Mana, Kizhakombu Koothattukulam, 686662, Ernakulam Dt., Kerala, India; Phone: 9400630608; Email: clinicalresearch@sreedhareeyam.com

ISSN: 2231-2196 (Print)

Received: 20.07 .2020
ISSN: 0975-5241 (Online)

Revised: 12.09 .2020
Accepted: 23.10 .2020 


\section{Case 1}

A 6-year-old boy presented with the blurring of vision that was more in his right eye (OD - oculus dexter) since birth. He was inclined to watch television very closely and had difficulty in distant vision. He was diagnosed with myopia by an ophthalmologist and was advised power spectacles, which he did not use. His birth history was normal, with his mother having a full-term normal delivery, and he attained all his milestones on time. His birth weight was $2.5 \mathrm{~kg}$. No significant illnesses were reported. His parents and brother do not complain of similar symptoms. The bowel was constipated and appetite, micturition, and sleep were normal. Review of systems and vital signs were within normal limits.

Unaided distant visual acuity (DVA)was LogMAR 1.477 OD and LogMAR 0.301 in his left eye (OS - oculus sinister). A - 11.00 diopter (D) lens with a $-1.50 \mathrm{D}$ cylinder and $50^{\circ}$ axis corrected his vision OD to LogMAR 0.778 , and a $-1.25 \mathrm{D}$ lens with a $-1.5 \mathrm{D}$ cylinder and $150^{\circ}$ axis corrected his vision OS to LogMAR 0.176. Near visual acuity was N6 in both eyes (OU - oculus uterque). Anterior segment examination showed a normal sclera and cornea, deep anterior chamber, and normal lens OU. Direct and consensual pupillary reflexes were sluggish OD and normal OS.

Posterior segment examination by ophthalmoscopy showed normal media in both eyes (OU), optic disc with normal cupto-disc ratio and absence of temporal crescent OU, healthy blood vessels with normal calibre OU, normal background with the absence of tessellations and retinal thinning OS, and lattice degeneration OD.

The patient was diagnosed with progressive myopia and was prescribed a 13-day course of inpatient Ayurvedic treatment. Unaided DVA improved to LogMAR 1.301 OD and other readings were maintained. A follow-up consultation demonstrated the same readings in unaided DVA.

\section{Case 2}

A 9-year-old boy presented with difficulty in distant vision OU for 5 years. His parents took him for an ophthalmic consultation when the symptoms first started. Power spectacles were prescribed, but the power kept on increasing. His mother's pregnancy and labour were normal, and delivery was full-term and without complications. His mother and sister suffer from visual complaints. He had no significant illnesses in the past. Bowel, appetite, micturition, and sleep were normal. His review of systems and vital signs were within normal limits.

Unaided DVA was LogMAR 1.079 OD and LogMAR 0.778 OS, aided DVA was LogMAR 0.176 OD and LogMAR 0 OS, and NVA was N6 OU. Anterior segment examination showed a large cornea OU, deep anterior chamber OU, and normal findings to the sclera and lens OU. Direct and consensual pupillary reflexes were sluggish OU. Posterior seg- ment examination showed normal media OU, a normal optic disc with a cup-to-disc ratio of $\mathrm{O} .3 \mathrm{OU}$, healthy blood vessels with normal calibre OU, and normal background OU. The patient was diagnosed with myopia and was advised inpatient management. He underwent two courses of management lasting 22 days altogether.

Unaided DVA at discharge after the first course of treatment was LogMAR 1 OD and LogMAR 0.602 OS and aided DVA was LogMAR 0.176 OD and LogMAR 0.301 OS. The same readings were maintained at a subsequent follow-up. Another follow-up demonstrated improvement in aided DVA to LogMAR 0 OU Unaided DVA reduced to LogMAR 0.778 OS at another follow-up. Unaided DVA at admission for the second course of treatment demonstrated LogMAR 1 OU, aided DVA at LogMAR 0.176 OD and LogMAR 0.477 OS, and were maintained at discharge.

\section{Case 3}

A 5-year-old girl presented with a defective distant vision for 2 months. Her guardian reported that this was elicited during a routine ophthalmic exam done 2 months ago. No treatment was offered. Her mother and elder brother both suffer from defective vision. No significant past illnesses were elicited. Bowel, micturition, appetite, and sleep were normal. Review of systems and vital signs were within normal limits.

Unaided DVA was LogMAR 0.176 OU and NVA was N6 OU. Anterior segment examination revealed a normal cornea and sclera OU, deep anterior chamber OU and normal lens OU. Direct and consensual pupillary reflexes were sluggish OU. Posterior segment examination revealed a normal media OU, a normal optic disc with a cup-to-disc ratio of $0.3 \mathrm{OU}$, healthy blood vessels with normal calibre OU, and normal background OU. The patient has advised inpatient management. She underwent two courses of treatment lasting 22 days altogether.

Unaided DVA OU was maintained at discharge after the first course of treatment. A subsequent follow-up demonstrated a similar reading OU. Refraction done at the next followup demonstrated that a 0.5 diopter (D) spherical lens with $-0.75 \mathrm{D}$ cylinder and $50^{\circ}$ axis corrected the unaided DVA OD to LogMAR 0; and a $0.5 \mathrm{D}$ spherical lens with $-1.00 \mathrm{D}$ cylinder and $140^{\circ}$ axis corrected DVA OS to LogMAR 0 . Unaided DVA OD improved to LogMAR 0 OU at the next followup. DVA was LogMAR 0 OD and LogMAR 0.176 OS at admission for her second course of treatment, and the same readings were reported at discharge. A subsequent follow-up showed unaided DVA of LogMAR 0 OU.

\section{Additional Information}

As some of the courses of treatment occurred during the COVID-19 pandemic and subsequent nationwide lock-down, a specialized questionnaire and health screening protocol were 
administered before admission for those courses. All three patients and their bystanders showed no symptoms or signs of the virus.

Vulnerability assessment is done before treatment categorized the patients into the pediatric group with visual deficits. No history of disorientation, trauma, motility deficit and impaired judgment were elicited.

In addition to this, the patient no. 1 was administered a nutritional assessment before admission. Although found to have normal nutritional status, he was deemed to be underweight. He was advised to include foods rich in vitamins A, C, and E, coloured fruits, and green leafy vegetables in his diet.

The patients' treatment protocols were tailored based on their Ashta Sthana Pariksha (eight methods of examination) ${ }^{9}$ and Dasavidha Pariksha (ten methods of examination) ${ }^{10}$ (Table 1) and involved administration of oral medicines (Table 2) and external ocular and head therapies (Table 3). Panchakarma (bio-purification) was not administered because the patients were under 10 years old.

Each case is chronologically organized in a timeline of events. (Tables 4-6).

All medicines were manufactured by Sreedhareeyam Farmherbs India, Pvt. Ltd., the hospital's GMP (Good Manufacturing Practices)-certified drug manufacturing unit.

\section{DISCUSSION}

The symptoms of the patients may be compared with Dvitiya Patalagata Dosha (affliction of the second layer of the eye by senses of humour) as per the Ayurvedic classics. Acarya Vagbhata describes this condition as Tamira. The feature of Timira that matches the symptoms of the patients is "Durantikastham Rupam ca (patient is unable to perceive distant objects)". ${ }^{11}$ Invasion of the third Patala is described as Timira by Acarya Susruta and Kaca by Acarya Vagbhata.

Ayurveda explains that pediatric patients may be prescribed the same medicines and treatments prescribed for adults but in a lower dosage and intensity. Qualities of medicines used for children are Mrdu (mild), Laghu (light), Madhura (sweet), Surabhi (pleasant odour), Samsamana (pacifying), and Hetu Viparita (antagonistic to the cause). These are because the medicines should not affect Dhatus too much and be both palatable and easy to assimilate.

Panchakarma, usually advocated in the management of Drishtigata Rogas (diseases of vision) including Timira, is contraindicated in children, especially those under the age of 10. Also, medicines employed should not be too Tikshna (sharp). These are due to the Saukumaryata (tender and delicate body structure), Alpakayata (under-developed organs), Vividha Anna Anupasevana (unfit GIT to receive all types of food), Aparipakva Dhatu (tissues under the progression of transformation), Aklesha Sahatva (stress intolerance), and Asampurna Bala (poor immunity).

The oral medicines were Cakshushya (good for eyes), Brmhana (nourishing), and Vata Hara (pacify Vata). Also, Asvagandharishta was Dipana (digestive) and Pacana (carminative). The medicines for external therapy promoted vision and strengthened both the eye as well as the nerves. The use of more Snigdha (unctuous) medicines is for both Pushti (nourishment) as well as relieving Timira, a Nanatmaja Vikara (of Vata according to Caraka Samhita.

Wisetone is prepared from Asparagus racemosus Linn., Zingiber officinale Rosc., Piper longum Linn., Piper nigrum Linn., Holostemma adakodien R.Br., and Glycyrrhiza glabra Linn., and enhances activity of the neurons. Kasyapa Ghrta and Kasyapa Kvatha, prepared from ingredients such as Terminalia chebula Retz., Terminalia bellerica Linn., Emblica officinalis Gaertn., Adathoda vasica Nees., and Berberis aristata DC, is indicated in Drishti Rogas. Jatavedha Ghrta is prepared from Terminalia chebula Retz., Terminalia bellerica Linn, Emblica officinalis Gaertn., and Holostemma adakodien R.Br., and is used for Tarpana in Drishti Rogas. Ananta Ghrta is prepared from Cedrus deodara Linn., and Holoostemma adakodien R.Br., and is also used for Tarpana in Drishti Rogas. Eye Plus, prepared from Terminalia chebula Retz., Terminalia bellerica Linn., Emblica officinalis Gaertn., and Picorrhiza kurroa Royle ex. Benth, is Ropana by nature and indicated for all eye conditions. Sunetra Junior is prepared from Nelumbo nucifera Gaertn., Ocimum sanctum Linn., Cinnamomum camphora (L.) Presl., and is indicated in eye conditions of patients under 16 years of age. Mukulanjana, prepared from Moringa oleifera Lam., Santalum album Linn., and red ocher $\left(\mathrm{Fe}_{2} \mathrm{O}_{3}\right)$, is indicated in myopia. Netramrtam is prepared from Tinospora cordifolia Miers., Berberis aristata DC., and Santalum album Linn., and is indicated in all eye conditions. Vinayakanjana is prepared from Nelumbo nucifera Gaertn., and distilled water, and is indicated in all eye diseases.

Netra Dhara, a variety of classical Seka ${ }^{12}$ was done to keep the eyes cleansed and to prevent excess increase of Kapha due to external application of Sneha. Anjana, which was done in the manner of classical Ascyotana ${ }^{13}$, was to promote vision to the eyes. Drishti Prasadana and Tarpana were done to strengthen the nerves and to promote vision. The Sneha used for both procedures were Vata Hara Anna Lepa was done for further pacification of Vata.

\section{CONCLUSION}

The main challenge in these patients was the improvement of vision. However, the improvement was observed, primarily due to healthy Dhatus being formed by the treatments, 
and that the bodies of the children were able to acclimatize to the medicines. Usage of medicines that were Brmhana, Samana, Mrdu, and Madhura, as well as external therapies that employed application of Ghrta and Taila facilitated the formation of a healthy physique as well as strengthened the nerves. The results of this series may be validated with largescale sample trials and studies.

\section{ACKNOWLEDGEMENT}

The authors thank Sreedhareeyam Ayurvedic Eye Hospital and Research Center, and Sreedhareeyam Farmherbs India Pvt. Ltd., for their help in preparing this case report.

Conflicts of Interest: None declared

Sources of Funding: None declared

\author{
Abbreviations: \\ DVA: distant visual acuity \\ NVA: near visual acuity \\ OD: oculus dexter \\ OS: oculus sinister \\ OU: oculus uterque
}

\section{REFERENCES}

1. The International Agency for the Prevention of Blindness, Global Vision Impairment Facts, 2020, Available from https://www. iapb.org/vision-2020/who-facts/

2. Fricke TR, Jong M, Naidoo KS, et al, Global prevalence of vision impairment associated with myopic macular degeneration and temporal trends from 2000-2050: a systematic review, metaanalysis, and modelling. Br J Ophthal 2018; 102(7): 855-862.

3. Wong HB, Machin D, Tan SB, Wong TY, Saw SM, Visual impairment and its impact on health-related quality of life in adolescents, Am J Ophthal 2009; 147(3):505-511.

4. George S, Joseph BB, Paul K. A Study on Myopia among the Students of a Dental College in Kerala. Int J Cur Res Rev 2015;7(10): 61-65.

5. Mehta N, Wen A. Myopia: A Global Epidemic: An Overview of the Problem and Efforts to Address It. Retina Today September 2019, 52-55

6. Smith TS, Frick KD, Holden BA, Fricke TR, Naidoo KS. Potential lost productivity resulting from the global burden of uncor- rected refractive error. Bull World Health Org, 2009; 87(6):431437.

7. Gwiazda J. Treatment options for myopia. Optometry Vision Sci. 2009; 89(6): 624-628.

8. Gagnier J, Kienle G, Altman DG, Moher D, Sox H, Riley DS, CARE group. The CARE guidelines: Consensus-based clinical case-reporting guideline development. Global Adv Health Med 2013;2(5):38-43

9. Kumari A, Tiwari PV. Yogaratnakara: A Complete Treatise on Ayurveda, Part I, Chaukhambha Vishwabharati, Varanasi, First Edition, 2010, 7-20.

10. Sharma RK, Dash B. Caraka Samhita: Text with English Translation and Critical Exposition based on Cakrapani Datta's Ayurveda Dipika, Vol. II, Chaukhambha Sanskrit Series Office, Varanasi, Reprint 2013; 260-278.

11. Murthy KRS. Ashtangahrdaya of Vagbhata: Text, English Translation, Notes, Appendices, and Index, Vol. III: Uttara Sthana, Krishnadas Academy, Varanasi, 2000, pg. 121.

12. Murthy PHC. Sarngadhara Samhita: Text with English Translation, Chaukhambha Sanskrit Series Office, Varanasi, 2013;188.

13. Murthy KRS. Ashtanga Hrdaya: Text, English Translation, Notes, Appendices, and Index, Vol. 1: Sutra and Sarira Sthana, Krishnadas Academy, Varanasi, 100.

\section{Previous Papers Published in the International Journal of Current Research and Review:}

- Narayanan Namboothiri Narayanan, Aravind Kumar, Krishnendu Sukumaran, Agaja Peethambaran Leena, An Ayurvedic Protocol to Manage Retinitis Pigmentosa - A Case Report, International Journal of Current Research and Review, 2020;12(13), 25-32

- Narayanan Namboothiri Narayanan, Aravind Kumar, Krishnendu Sukumaran. An Ayurvedic Protocol to Manage Rhegmatogenous Retinal Detachment and the Resultant Macular Hole - A Case Report International Journal of Current Research and Review. 2020;12(14):10-16

- Narayanan Namboothiri Narayanan, Sreekala Nelliakkattu Parameswaran, Sreekanth Parameswaran Namboothiri, Anjaly Naduvathu Vasudevan, Aravind Kumar, Krishnendu Sukumaran. Management of Proliferative Diabetic Retinopathy and its Associated Conditions using Ayurvedic Therapies: A Case Series International Journal of Current Research and Review. 2020;12(17):10-22 
Table 1: Ashtasthana Pariksha and Dasavidha Pariksha for the Three Patients

\begin{tabular}{|c|c|c|c|}
\hline Parameter & Patient 1 & Patient 2 & Patient 3 \\
\hline \multicolumn{4}{|c|}{ Ashtasthana Pariksha (8 methods of examination) } \\
\hline Nadi (pulse) & Kapha Pitta & Kapha Pitta & Kapha Vata \\
\hline Mutra (urine) & Prakrta & Prakrta & Prakrta \\
\hline Mala (excreta) & Prakrta & Prakrta & Prakrta \\
\hline Jihva (tongue) & Anupalipta & Anupalipta & Anupalipta \\
\hline Sabda (sound) & Prakrta & Prakrta & Prakrta \\
\hline Sparsa (touch) & Anushnasita & Anushnasita & Anushnasita \\
\hline Drk (sight) & Vaikrta & Vaikrta & Vaikrta \\
\hline Akrti (appearance) & Prakrta & Prakrta & Prakrta \\
\hline \multicolumn{4}{|c|}{ Dasavidha Pariksha (10 methods of examination) } \\
\hline Prakrti (somatic constitution) & Kapha Pitta & Pitta Kapha & Kapha Vata \\
\hline Vikrti (status of disease) & $\begin{array}{l}\text { - Dosha: Kapha } \\
\text { - Dhatu: Rasa, } \\
\text { Rakta }\end{array}$ & $\begin{array}{l}\text { - Dosha: Kapha } \\
\text { - Dhatu: Rasa, Rakta }\end{array}$ & $\begin{array}{l}\text { - Dosha: Kapha, Vata } \\
\text { - Dhatu: Rasa, Rakta }\end{array}$ \\
\hline $\begin{array}{l}\text { Sara } \\
\text { (essence of Dhatus) }\end{array}$ & Rakta & Mamsa & Rakta \\
\hline $\begin{array}{l}\text { Samhanana } \\
\text { (compactness of body parts) }\end{array}$ & Avara & Avara & Avara \\
\hline $\begin{array}{l}\text { Pramana } \\
\text { (measurement of body parts) }\end{array}$ & Avara & 'Avara & Avara \\
\hline Sattva (psyche) & Avara & Avara & Avara \\
\hline Satmya (habituation) & Avara & Avara & Avara \\
\hline $\begin{array}{l}\text { Ahara Sakti } \\
\text { (capacity of digestion) }\end{array}$ & Avara & Avara & Avara \\
\hline $\begin{array}{l}\text { Vyayama Sakti } \\
\text { (capacity for exercise) }\end{array}$ & Avara & Avara & Avara \\
\hline Vaya (age) & Bala & Bala & Bala \\
\hline
\end{tabular}

Table 2: Oral Medicines for the Three Patients

\begin{tabular}{|c|c|c|c|c|c|}
\hline Medicine & Dose & Anupana (post-prandial drink) & Case & Prescription & Duration \\
\hline \multirow[t]{4}{*}{ Netraraksha Kvatha* } & $5 \mathrm{~mL}$ & Sukhoshna Jala & 2 & Inpatient & 9 days \\
\hline & $5 \mathrm{~mL}$ & Asvagandharishta & & & 12 days \\
\hline & $10 \mathrm{~mL}$ & Sukhoshna Jala & 2 & Discharge & 2 months \\
\hline & $40 \mathrm{~mL}$ & Sukhoshna Jala & 3 & Inpatient & 19 days \\
\hline \multirow[t]{3}{*}{ Saptamrta Lauha } & 1 tablet & Sukhoshna Jala & $\mathbf{1}$ & Inpatient & 14 days \\
\hline & & & 2 & Inpatient & 9 days \\
\hline & & & 3 & Inpatient & 10 days \\
\hline Jivanti Curna & 1 tablespoon & Honey & $\mathbf{1}$ & Inpatient & 14 days \\
\hline \multirow[t]{4}{*}{ Kasyapa Ghrta* } & 1 tablespoon & - & $\mathbf{1}$ & Inpatient & 14 days \\
\hline & & & 1 & Discharge & 2 months \\
\hline & & & 2 & Discharge & 2 months \\
\hline & & & 3 & Discharge & 2 months \\
\hline \multirow[t]{3}{*}{ Wisetone* } & 1 tablespoon & - & 1 & Inpatient & 14 days \\
\hline & & & 1 & Discharge & 2 months \\
\hline & & & 3 & Discharge & 2 months \\
\hline \multirow[t]{2}{*}{ Asvagandharishta } & $10 \mathrm{~mL}$ & Netraraksha Kvatha & 2 & Inpatient & 12 days \\
\hline & & & 3 & Inpatient & 19 days \\
\hline
\end{tabular}


Table 3: External Therapies for the Three Patients

Treatment Medicine Case Prescription Duration Procedure of Therapy

Netra Kriyakalpa (local ophthalmic therapies)

\begin{tabular}{|c|c|c|c|c|}
\hline \multirow[t]{3}{*}{ Netra Dhara } & \multirow[t]{3}{*}{ Kasyapam Kvatha* } & $\mathbf{1}$ & Inpatient & 7 days \\
\hline & & 2 & Inpatient & 18 days \\
\hline & & 3 & Inpatient & 11 days \\
\hline Ascyotana & Jatavedha Ghrta* & $\mathbf{1}$ & Inpatient & 6 days \\
\hline \multirow[t]{11}{*}{ Anjana } & \multirow[t]{4}{*}{ Eye Plus* } & $\mathbf{1}$ & Inpatient & 7 days \\
\hline & & 2 & Inpatient & 13 days \\
\hline & & & Discharge & 2 months \\
\hline & & 3 & Inpatient & 6 days \\
\hline & \multirow[t]{3}{*}{ Sunetra Junior* } & $\mathbf{1}$ & Discharge & 2 months \\
\hline & & 3 & Inpatient & 3 days \\
\hline & & 3 & Discharge & 2 months \\
\hline & \multirow[t]{2}{*}{ Netramrtam* } & 3 & Inpatient & 6 days \\
\hline & & 3 & Discharge & 2 months \\
\hline & Candanadi Anjana & 2 & Inpatient & 18 days \\
\hline & Mukulanjana* & 3 & Inpatient & 5 days \\
\hline \multirow{3}{*}{$\begin{array}{l}\text { Drishti Prasa- } \\
\text { dana }^{\wedge}\end{array}$} & Vinayakanjana* & $\mathbf{1}$ & Inpatient & 7 days \\
\hline & \multirow{2}{*}{$\begin{array}{l}\text { Kshirabala } 21 \\
\text { Avartana }\end{array}$} & 2 & Inpatient & 9 days \\
\hline & & 3 & Inpatient & 4 days \\
\hline
\end{tabular}

- The patient lay supine and was asked to blink as the decoction was poured in a thin stream from a height of 2 inches over the eyes.

- The patient lay supine and one drop of the medicine was instilled into the sub-conjunctival sac. The patient was asked to slowly rotate the eyes after instillation with the eyes closed.

- The lukewarm medicine was taken and massaged over the forehead and the upper and lower eyelids from the inner canthus to the outer canthus; theinner aspect of the maxilla, outer canthus, inner canthus, supra-orbital margins, and eyebrows using the thumb and index fingers for 2-3 minutes each. Adequate pressure was applied to each of the points.

Eye Massage

1 Discharge 2 months

- 2 drops of the lukewarm oil were applied to the eyelids and massaged.

Bandhana Vinayakanjana* 2

Flowers of Malati

$1 \quad$ Inpatient

6 days

- Malati Pushpa was applied to the eyes and bandaging was done for one hour.

Tarpana

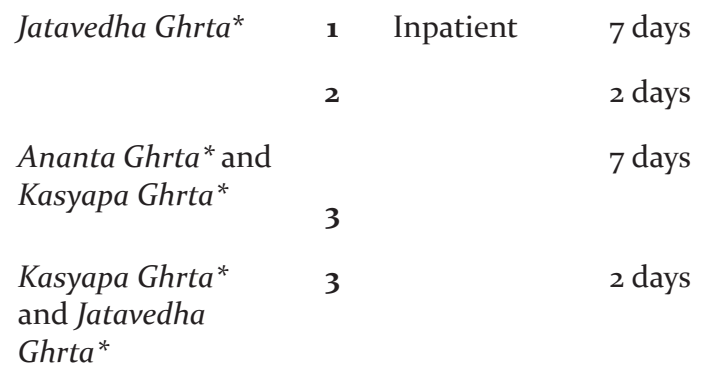

- A circular fence was constructed around the orbits using Masha flour and water. The medicine, made lukewarm, was poured into the cavities. The patient was asked to blink frequently. 


\begin{tabular}{|c|c|c|c|c|c|}
\hline Anna Lepa & Sashtika Sali & 2 & & 1 day & $\begin{array}{l}\text { - A paste of Sashtika Sali made warm was applied } \\
\text { over the eyelids. }\end{array}$ \\
\hline \multicolumn{6}{|c|}{ Treatments for the Head } \\
\hline Siroveshtana $^{\wedge}$ & $\begin{array}{l}\text { Powder of Bala } \\
\text { and Vidari mixed } \\
\text { with Kacchuradi } \\
\text { Curna and Balas- } \\
\text { vagandhadi Taila }\end{array}$ & $\mathbf{1}$ & Inpatient & 5 days & $\begin{array}{l}\text { A semisolid paste prepared by mixing } 459 \text { of all ingre- } \\
\text { dients with the desired liquid medium was smeared } \\
\text { over a Cora cloth and applied to the head (area with } \\
\text { the paste facing inwards) in the following manner: } \\
\text { - One end of the cloth was anchored above the right } \\
\text { ear. } \\
\text { - The cloth was wrapped over the forehead above } \\
\text { the eyebrows and towards the left ear. } \\
\text { - From the left ear, the cloth was wrapped around } \\
\text { the back of the head and brought upwards around } \\
\text { the head while the vertex is avoided. } \\
\text { - The other end of the cloth was applied to the top } \\
\text { of the head. }\end{array}$ \\
\hline Sirodhara & $\begin{array}{l}\text { Balasvagandhadi } \\
\text { Taila and Sasanka } \\
\text { Taila }\end{array}$ & 3 & Inpatient & $\begin{array}{l}4 \text { days } \\
11 \text { days } \\
8 \text { days }\end{array}$ & $\begin{array}{l}\text { The patient lay supine on the treatment table. A } \\
\text { thin cloth band was tied around the forehead. A } \\
\text { pot with an } 8 \mathrm{~mm} \text { hole in the center of the bottom } \\
\text { was suspended above the patient's head with } \\
\text { ropes. The lukewarm was poured into the pot and } \\
\text { was allowed to drain through the hole onto the } \\
\text { patient's head. }\end{array}$ \\
\hline
\end{tabular}

Table 4: Timeline of Events for Case 1

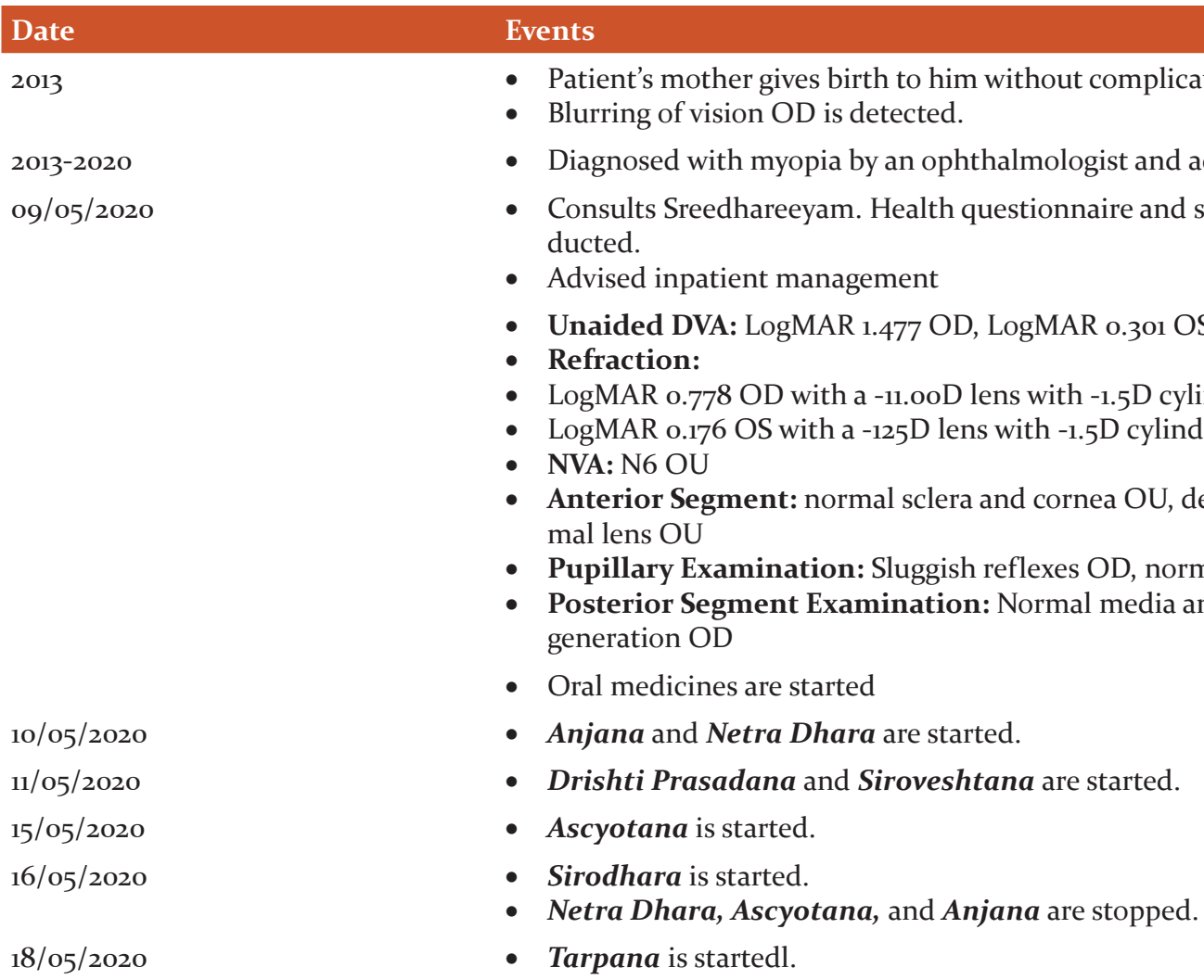


Table 4: (Continued)

\begin{tabular}{|c|c|}
\hline Date & Events \\
\hline \multirow[t]{2}{*}{$21 / 05 / 2020$} & - All treatments and oral medicines are stopped. \\
\hline & $\begin{array}{l}\text { - Unaided DVA: LogMAR 1.301 OD, LogMAR } 0.301 \text { OS } \\
\text { - Refraction: } \\
\text { - LogMAR o.778 OD with a -11.ooD lens with }-1.5 \text { D cylinder and } 50^{\circ} \text { axis } \\
\text { - LogMAR o.176 OS with a -125D lens with -1.5D cylinder and } 150^{\circ} \text { axis } \\
\text { - NVA: N6 OU }\end{array}$ \\
\hline $14 / 07 / 2020$ & $\begin{array}{l}\text { - Unaided DVA: LogMAR 1.301 OD, LogMAR o.301 OS } \\
\text { - Refraction: } \\
\text { - LogMAR o.778 OD with a -11.ooD lens with -1.5D cylinder and } 50^{\circ} \text { axis } \\
\text { - LogMAR o.176 OS with a -125D lens with -1.5D cylinder and } 150^{\circ} \text { axis } \\
\text { - NVA: N6 OU }\end{array}$ \\
\hline
\end{tabular}

Table 5: Timeline of Events for Case 2

\begin{tabular}{|c|c|}
\hline Date & Events \\
\hline $04 / 2019$ & - Patient develops difficulty in distant vision OU \\
\hline $04 / 2019-09 / 2019$ & $\begin{array}{l}\text { - Ophthalmic consultation is sought. } \\
\text { - He is diagnosed with myopia and is prescribed power spectacles. } \\
\text { - Uses them, but power increases }\end{array}$ \\
\hline 07/09/2019 & $\begin{array}{l}\text { - } \text { First consultation at Sreedhareeyam Hospital } \\
\text { - Advised inpatient management } \\
\text { - Unaided DVA: LogMAR 1.079 OD and LogMAR o.778 OS } \\
\text { - } \text { Aided DVA: LogMAR o.176 OD and LogMAR o.301 OS } \\
\text { - Anterior Segment: Large cornea OU, deep anterior chamber OU, normal sclera and lens } \\
\text { - PU } \\
\text { - Pupillary Examination: Within normal limits OU } \\
\text { - } \text { Admitted for his firstg course of treatment } \\
\text { - Oral medicines are started }\end{array}$ \\
\hline o8/09/2019 & - Netra Dhara, Ascyotana, Sirodhara, Drishti Prasadana, and Anjana are started. \\
\hline 13/09/2019 & - Tarpanais stared. \\
\hline $16 / 09 / 2019$ & $\begin{array}{l}\text { - All treatments and oral medicines are stopped. } \\
\text { - Unaided DVA: LogMAR } 1 \text { OD and LogMAR o.6oz OS } \\
\text { - Aided DVA: LogMAR o.176 OD and LogMAR o OS } \\
\text { - NVA: N6 OU }\end{array}$ \\
\hline $02 / 11 / 2019$ & $\begin{array}{l}\text { - Unaided DVA: LogMAR } 1 \text { OD and LogMAR o.6o2 OS } \\
\text { - Aided DVA: LogMAR 0.176 OD and LogMAR o OS } \\
\text { - NVA: N6 OU }\end{array}$ \\
\hline $04 / 01 / 2020$ & $\begin{array}{l}\text { - Unaided DVA: LogMAR } 1 \text { OD and LogMAR o.6o2 OS } \\
\text { - Aided DVA: LogMAR o OU } \\
\text { - NVA: N6 OU }\end{array}$ \\
\hline $27 / 02 / 2020$ & $\begin{array}{l}\text { - Unaided DVA: LogMAR } 1 \text { OD and LogMAR o.778 OS } \\
\text { - } \text { Aided DVA: LogMAR o OU } \\
\text { - NVA: N6 OU }\end{array}$ \\
\hline
\end{tabular}


Table 5: (Continued)

\begin{tabular}{ll} 
Date & Events \\
\hline $13 / 05 / 2020$ & Patient reports for his second course of treatment \\
& - Unaided DVA: LogMAR 1 OU \\
& - NVA: N6 OU \\
& - Oral medicines are started. \\
& - Netra Dhara, Anjana, and Sirodhara are started. \\
$14 / 05 / 2020$ & - Drishti Prasadana is started. \\
$17 / 05 / 2020$ & - Tarpana is started. \\
$21 / 05 / 2020$ & - All treatments are stopped. \\
$24 / 05 / 2020$ & - Unaided DVA: LogMAR 1 OU \\
& - Aided DVA: LogMAR o.176 OD and LogMAR 0.477 OS \\
& NVA: N6 OU
\end{tabular}

\section{Table 6: Timeline of Events for Case 3}

\begin{tabular}{|c|c|}
\hline Date & Events \\
\hline $07 / 2019$ & - Patient reports defective distant vision that was elicited on a routine ophthalmic examination \\
\hline 07/09/2019 & $\begin{array}{l}\text { - Patient reports for her first course of treatment. } \\
\text { - Unaided DVA: LogMAR o.176 OU } \\
\text { - NVA: N6 OU } \\
\text { - Anterior Segment: Deep anterior chamber OU, large cornea OU, normal sclera and lens OU } \\
\text { - Pupillary examination: Sluggish responses to direct and consensual reflexes OU. } \\
\text { - Posterior segment: Normal media, optic disc, blood vessels, and background OU }\end{array}$ \\
\hline o8/o9/2019 & - Oral medicines are started \\
\hline 09/09/2019 & - Netra Dhara, Anjana, Drishti Prasadana, and Sirodhara are started. \\
\hline 14/09/2019 & - Tarpana is started. \\
\hline 16/09/2019 & $\begin{array}{l}\text { - All oral medicines and treatments are stopped. } \\
\text { - Unaided DVA: LogMAR 0.176 OU } \\
\text { - NVA: N6 OU }\end{array}$ \\
\hline $02 / 11 / 2019$ & $\begin{array}{l}\text { - Refraction } \\
\text { - LogMAR o OD by a o.5D lens with -0.75D cylinder and } 50^{\circ} \text { axis } \\
\text { - LogMAR o OS by a o.5D lens with - } 1.00 \text { cylinder and } 140^{\circ} \text { axis }\end{array}$ \\
\hline 04/01/2019 & $\begin{array}{l}\text { - Unaided DVA: LogMAR o OD, LogMAR o.176 OS } \\
\text { - NVA: N6 OU }\end{array}$ \\
\hline $27 / 02 / 2019$ & $\begin{array}{l}\text { - Unaided DVA: LogMAR o OD, LogMAR o.176 OS } \\
\text { - NVA: N6 OU }\end{array}$ \\
\hline $13 / 05 / 2020$ & $\begin{array}{l}\text { - Patient reports for a second course of treatment. } \\
\text { - Unaided DVA: LogMAR o OD, LogMAR o.176 OS } \\
\text { - NVA: N6 OU } \\
\text { - Oral medicines are started. }\end{array}$ \\
\hline $14 / 05 / 2020$ & - Netra Dhara, Anjana, and Thalam are started. \\
\hline $17 / 05 / 2020$ & - Tarpana is started. \\
\hline $22 / 05 / 2020$ & $\begin{array}{l}\text { - All medicines and treatments are stopped. } \\
\text { - Unaided DVA: LogMAR o OD, LogMAR o.176 OS } \\
\text { - NVA: N6 OU }\end{array}$ \\
\hline $02 / 07 / 2020$ & $\begin{array}{l}\text { - Unaided DVA: LogMAR o OU } \\
\text { - NVA: N6 OU }\end{array}$ \\
\hline
\end{tabular}

*Patented medicine of Sreedhareeyam Farmherbs India, Pvt. Ltd.

$\wedge^{\wedge}$ Therapeutic protocol of Sreedhareeyam Ayurvedic Eye Hospital and Research Center 